\title{
Perancangan Komunikasi Data VSAT Mobile Dengan Frekuensi KU-Band Pada Satelit Palapa
}

\author{
Aditya Budi, Rianto Nugroho \\ Program Studi Teknik Elektro, Fakultas Teknik dan Sains, Universitas Nasional \\ Korespondensi : riantnugroho@yahoo.com
}

\begin{abstract}
ABSTRAK. Perancangan sistem komunikasi dengan menggunakan satelit di latar belakangi dengan perkembangan teknologi informasi yang demikian pesat dan permintaan akan komunikasi yang tinggi. Frekuensi C-band yang dipakai saat ini, tidak akan mampu menampung kebutuhan informasi user yang terus meningkat. Solusi untuk mengatasi masalah tersebut adalah dengan menggunakan frekuensi Ku-band. Pada perancangan vsat ini menggunakan vsat motorized untuk mempermudah sistem pointing dan dapat dibawa kemana-mana atau mobile. Namun penggunaan frekuensi $\mathrm{Ku}$-band tidak mudah untuk diterapkan, banyak hal yang mempengaruhinya. Dalam perancangan sistem komunikasi ini, dibahas masalah propagasi pada frekuensi $\mathrm{Ku}$-band, dimana masalah utama yang timbul diantaranya propagasi gelombang radio yang mengalami redamannya yang cukup besar. Satelit yang digunakan adalah satelit Palapa yang memiliki jangkauan global yang berada pada orbit GEO.
\end{abstract}

Kata kunci: Frekuensi Ku- band, redaman, satelit palapa, VSAT mobile.

\begin{abstract}
The design of communication systems using satellites in the background with the rapid development of information technology and the demand for high communication. The current $C$-Band frequencies will not be able to accommodate the ever-increasing need for user information. The solution to solve the problem is to use Ku-band frequency. In the design of this vsat using motorized vsat to facilitate the pointing system and can be taken anywhere or mobile. But the use of Ku-band frequencies is not easy to implement, many things are affecting it. In the design of this communication system, discussed the problem of propagation on the Ku-band frequency, where the main problems that arise among them the propagation of radio waves that suffer a considerable attenuation. The satellites used are the Palapa satellites that have global coverage located in GEO orbit.
\end{abstract}

Keywords: Ku-band frequency, attenuation, palapa satellite, VSAT mobile.

\section{PENDAHULUAN}

Frekuensi C-band yang dipakai saat ini, tidak akan mampu menampung kebutuhan informasi user yang terus meningkat. Solusi untuk mengatasi masalah tersebut adalah dengan menggunakan frekuensi Ku-band yang memiliki bandwidth transponder sampai dengan 500MHz. Namun penggunaan frekuensi Ku-band tidak mudah untuk diterapkan, banyak hal yang mempengaruhinya antara lain: redaman hujan, redaman awan, redaman gas-gas atmosfir, dan loss tracking. Transponder Ku-band, dengan kapasitas yang besar dan mampu melayani user dengan kecepatan yang tinggi. apakah sistem ini bisa diterapkan di Indonesia khususnya dengan menggunakan satelit GEO khususnya pada Satelit Palapa.

\section{LANDASAN TEORI}

\section{Sistem Komunikasi Satelit}

Sistem komunikasi satelit secara umum terdiri dari sebuah satelit yang berfungsi sebagai stasiun pengulang (repeater) di angkasa yang berhubungan dengan beberapa stasiun bumi. Sistem komunikasi satelit ini umumnya digunakan untuk daerah yang sulit dijangkau oleh jaringan terestrial. Hal inilah yang menjadi kelebihan sistem komunikasi satelit dibandingkan dengan sistem teknologi komunikasi yang lain. Sistem komunikasi satelit mampu menjangkau daerahdaerah yang jauh dan dan terpencil dikarenakan cakupannya yang luas sehingga sangat sesuai 
dengan letak geografis Indonesia. Sistem komunikasi satelit pada dasarnya terdiri dari dua bagian yaitu:

- Ground Segment (Stasiun Bumi / Terminal)

Stasiun bumi bertugas untuk melakukan komunikasi dari dan ke space segment.

- Space Segment (Satelit)

Satelit komunikasi berfungsi sebagai repeater gelombang mikro di angkasa. Satelit ini akan menerima sinyal gelombang mikro yang dikirimkan dari stasiun bumi asal pada frekuensi yang diberikan (uplink) dan mengirimkan kembali ke stasiun bumi tujuan pada frekuensi yang berbeda (downlink). Satelit yang akan mengorbit mengelilingi bumi akan selalu tetap berada pada posisinya karena gaya sentripetal diimbangi dengan gaya tarikan bumi. Penentuan orbit merupakan hal yang sangat penting dan mendasar karena akan menentukan rugi dan waktu keterlambatan (delay time) dari transmisi, daerah cakupan bumi (earth coverage area), dan selang waktu dimana satelit dapat terlihat dari setiap daerah tertentu. Orbit satelit berdasarkan ketinggiannya dibagi menjadi:

- LEO (Low Earth Orbit). Satelit berada pada ketinggian kurang dari $2000 \mathrm{Km}$ (1250 mile). Pada orbit ini satelit memiliki periode rotasi 90 menit sampai 2 jam.

- MEO (Medium Earth Orbit). Satelit berada pada ketinggian $10000 \mathrm{Km}$ (6250 mile). Pada orbit ini satelit memiliki periode rotasi sekitar 6 jam.

- GEO (Geosynchronous Earth Orbit). Satelit berada pada ketinggian $35680 \mathrm{Km}(22300$ mile). Pada orbit ini satelit memiliki periode rotasi 24 jam.

\section{Band Frekuensi Satelit}

Satelit bekerja pada band frekuensi tertentu (spesific range). Band frekuensi tersebut terdiri dari frekuensi uplink yaitu frekuensi yang dikirimkan dari stasiun bumi atau ground terminal ke satelit dan frekuensi downlink yaitu frekuensi yang dikirimkan dari satelit ke stasiun bumi atau ground terminal.

TABEL 1. Band yang dipergunakan dalam Komunikasi Satelit

\begin{tabular}{|c|c|c|c|}
\hline BAND & UPLINK $(\mathrm{GHz})$ & DOWNLINK $(\mathrm{GHz})$ & Bandwidth $(\mathrm{MHz})$ \\
\hline $\mathrm{C}$ & $5,9-6,4$ & $3,7-4,2$ & 500 \\
\hline $\mathrm{X}$ & $7,9-8,4$ & $7,25-7,75$ & 500 \\
\hline $\mathrm{KU}$ & $14,2-14,4$ & $12,5-12,7$ & 500 \\
\hline $\mathrm{KA}$ & $27-30$ & $17-20$ & Not Fixed \\
\hline
\end{tabular}

\section{Effective Isotropic Radiated Power (EIRP)}

Salah satu parameter yang penting dari sistem VSAT adalah EIRP.

Sebuah pemancar yang isotropic dengan daya masukan yang sama, yaitu sebesar $\mathrm{GP}_{\mathrm{T}}$ akan menghasilkan kerapatan flux yang sama. Hasil ini yang disebut EIRP. Bentuk persamaannya dapat dilihat pada persamaan berikut;

Dimana:

$$
\begin{gathered}
\text { EIRP }=\text { GP }_{\mathrm{T}} \\
{[\text { EIRP }]=\left[\mathrm{P}_{\mathrm{T}}\right]+[\mathrm{G}] \mathrm{dBW}}
\end{gathered}
$$

$\mathrm{G}=$ gain antena pemancar

$\mathrm{P}_{\mathrm{T}} \quad=$ daya pada antena pemancar

Besarnya harga $\mathrm{P}_{\mathrm{T}}$ adalah nilai dari daya yang ada pada pemancar setelah dikurangi dengan rugi feeder. Feeder adalah saluran transmisi yang menghubungkan perangkat pemancar dengan antena pemancar VSAT seperti hubungan $[\mathrm{EIRP}]_{\mathrm{dB}}=\mathrm{P}_{\mathrm{TX}}(\mathrm{dBW})-\mathrm{L}_{\mathrm{FTX}}(\mathrm{dB})+\mathrm{G}_{\mathrm{dB}}$ 


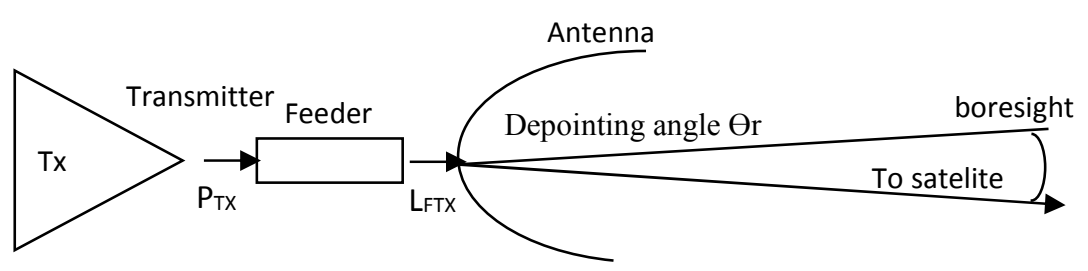

GAMBAR 1. Komponen antena pemancar VSAT

\section{Penguatan Antena (Antena Gain)}

Penguatan atau gain antena yang diperhatikan adalah daya masuk ke terminal antena, penguatan antena dapat didefinisikan sebagai perbandingan intensitas radiasi maksimum suatu antena dengan intensitas radiasi maksimum dari suatu antena pembanding, dengan daya masuk yang sama. Biasanya antena yang digunakan sebagai antena pembanding adalah antena isotropis dengan efisiensi $100 \%$.

$$
\mathrm{G}_{\max }(\mathrm{dBi})=10 \log \eta(\pi \mathrm{Df} / \mathrm{c})^{2}
$$

\section{Rugi Ruang Bebas (Free Space Loss)}

Pada setiap transmisi dengan menggunakan udara sebagai media transmisinya, maka akan mengalami redaman yang disebut rugi ruang bebas. Perhitungan besarnya ruang bebas yang terjadi pada link, yaitu dengan menggunakan persamaan 2.8 sebagai berikut:

$$
\operatorname{FSL}(\mathrm{dB})=20 \log (\mathrm{d})+20 \log (\mathrm{f})+92,44
$$

Dimana:

$$
\begin{aligned}
& \mathrm{f}=\text { frekuensi kerja }(\mathrm{GHz}) \\
& \mathrm{d}=\text { panjang lintasan propagasi }(\mathrm{Km})
\end{aligned}
$$

\section{Carrier to Noise}

Adalah parameter SNR yang paling penting dan sangat berpengaruh terhadap perencanaan sistem komunikasi VSAT. Link Budget digunakan untuk mendapatkan SNR. Secara umum persamaannya sebagai berikut:

$$
\mathrm{C} / \mathrm{N}=\mathrm{EIRP}-\mathrm{FSL}_{\mathrm{dB}}-(\text { rugi-rugi lain })+\mathrm{G} / \mathrm{T}_{\mathrm{sys}}-\mathrm{K}-10 \log \mathrm{B}
$$

Dimana:

$$
\begin{array}{ll}
\text { EIRP } & =\text { dapat dihitung dipersaman } 2.4 \\
\mathrm{FSL} & =\text { adalah rugi ruang bebas } \\
\mathrm{G} & =\text { Gain antena } \\
\mathrm{T}_{\text {sys }} & =\text { diperoleh dari persamaan } 2.11 \\
\mathrm{~K} & =\text { Konstanta Boltzmann's }=-228,6 \mathrm{dBW} \\
\mathrm{B} & =\text { Bandwidth Occupation }
\end{array}
$$

$$
(C / N) \text { total }=\frac{1}{\frac{1}{(C / N)^{U} p^{\text {tink }}}+\frac{1}{(C / N)^{D}}}
$$

\section{- Perhitungan C/N Uplink}

Persamaan uplink untuk transmisi dari stasiun bumi pemancar menuju satelit sebagai penerima dapat ditulis secara langsung dengan mensubstitusikan nilai-nilai kedalam persamaan dasar link dibaawah ini.

$$
\mathrm{C} / \mathrm{N}_{\mathrm{UP}}=\mathrm{EIRP}_{\mathrm{UP}}-\mathrm{L}_{\mathrm{TOT}}+\mathrm{G} / \mathrm{T}_{\mathrm{SAT}}-\mathrm{k}-10 \log \mathrm{B}
$$

\section{Dimana:}

EIRP $_{\text {UP: }}$ EIRP dari stasiun bumi pemancar

$\mathrm{L}_{\text {Tот }}$ : Uplink Path Loss 
$\mathrm{G} / \mathrm{T}_{\mathrm{SAT}}$ : Perbandingan Gain satelit terhadap noise temperature

$\mathrm{K} \quad$ : Konstanta Boltzman $=-228.6\left(\mathrm{dBW} /{ }^{\circ} \mathrm{K}-\mathrm{Hz}\right)$

B : Bandwidth Ocuupation

\section{- Perhitungan C/N Downlink}

Persamaan downlink untuk transmisi dari satelit menuju stasiun menuju stasiun bumi penerima dapat ditulis secara langsung dengan mensubtitusikan nilai-nilai kedalam persamaan dasar link dibawah ini:

$$
\mathrm{C} / \mathrm{N}_{\text {down }}=\mathrm{EIRP}_{\mathrm{SAT}}-\mathrm{L}_{\mathrm{TOT}}+\mathrm{G} / \mathrm{T}_{\mathrm{SB}}-\mathrm{k}-10 \log \mathrm{B}
$$

Dimana:

$\begin{array}{ll}\text { EIRP }_{\text {down }} & : \text { EIRP dari satelit } \\ \mathrm{L}_{\mathrm{TOT}} & : \text { Downlink Path Loss } \\ \mathrm{G} / \mathrm{T}_{\mathrm{SB}} & : \text { Perbandingan Gain stasiun bumi terhadap noise temperatur } \\ \mathrm{K} & : \text { Konstanta Boltzman }=-228.6\left(\mathrm{dBW} /{ }^{\circ} \mathrm{K}-\mathrm{Hz}\right) \\ \mathrm{B} & : \text { Bandwidth Ocuupation }\end{array}$

\section{VSAT (Very Small Aperture Terminal)}

VSAT merupakan sebuah teknologi yang memanfaatkan pancaran gelombang radio untuk melakukan pengiriman dan Penerimaan informasi (data, gambar, video, maupun suara). VSAT merupakan terminal berbentuk antena parabola berdiameter antara $0,9 \mathrm{~m}$ sampai dengan 3,8 $\mathrm{m}$, pada saat antena VSAT mengirimkan sebuah informasi ke satelit, maka informasi yang diterima oleh satelit akan dipantulkan atau dikirimkan ke terminal yang dituju dengan atau tanpa melewati satelit lain.

\section{Komponen VSAT (Very Small Aperture Terminal) \\ HUB Station}

HUB Station berfungsi untuk mengontrol seluruh operasi jaringan komunikasi. Pada hub station terdapatsebuah Server Network Management System (NMS) yang berfungsi untuk memberikan akses pada operator jaringan untuk memonitor dan mengontrol sebuh jaringan komunikasi melalui integrasi perangkat keras dan komponen - komponen perangkat lunak. Operator jaringan dapat memonitor, memodifikasi dan mendownload informasi konfigurasi individual ke masing-masing VSAT.

\section{Remote Station}

Sebuah remote VSAT memiliki komponen - komponen sebagai berikut:

- Outdoor Unit(ODU) terdiri dari dua bagian yaitu antena dan Radio Frequency Transmitter (RFT) pasang pada frame antenna dan dihubungkan secara internal ke feedhorn.

- Solid State Power Amplifier (SSPA)

- Up / Down Converter

- Indoor Unit (IDU)

\section{PERENCANAAN VSAT MOBILE SYSTEM}

Komunikasi satelit yang digunakan pada perancangan ini menggunakan satelit Geostasioner Palapa D yang beroperasi pada transponder linear, Hub, dan beberapa VSAT yang ditempatkan di wilayah tertentu. Hub dapat mengirimkan data dengan kecepatan $13.824 \mathrm{Mbps}$ ke masingmasing VSAT secara broadcast. 


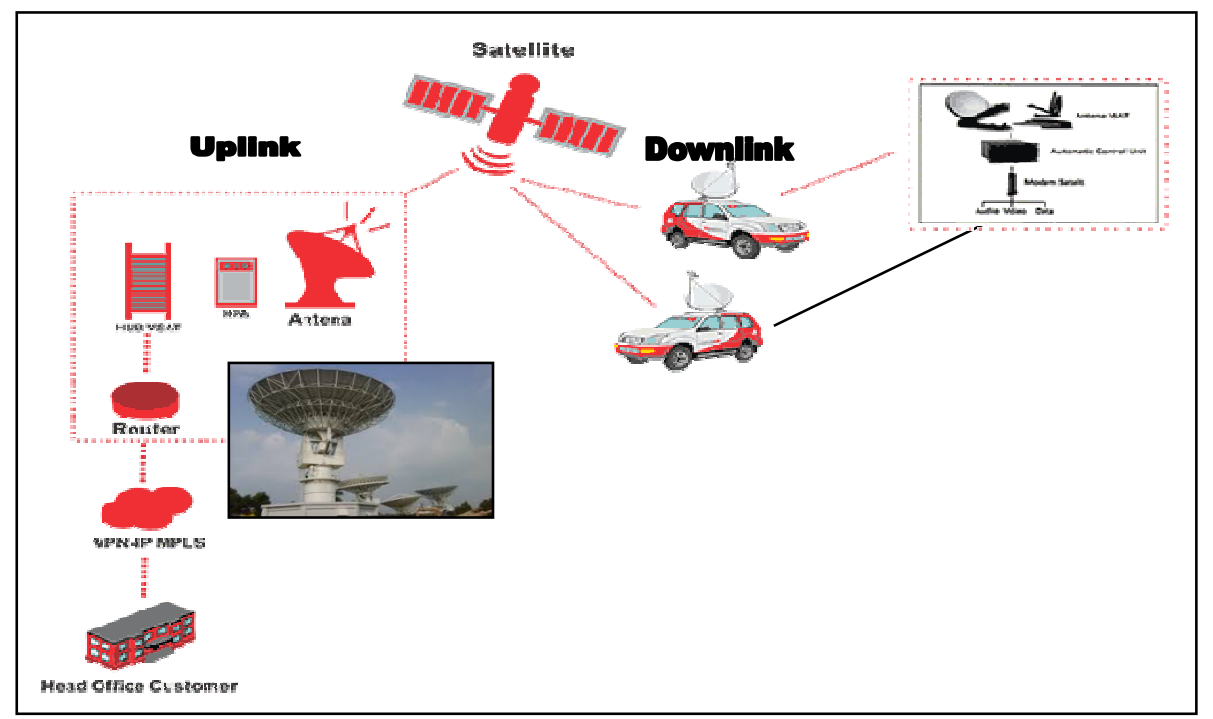

GAMBAR 2. Perancangan VSAT mobile system.

Dari gambar 2, terlihat bahwa perancangan sistem VSAT mobile ini menggunakan satu antena uplink yang akan mengirim sinyal ke satelit, kemudian diterima oleh satelit dan menguatkannya kembali sebelum sinyal tersebut dikirim kembali ke stasiun bumi sebagai penerima, parameter satelit seperti tabel 1 .

TABEL 1. Satelit parameter Palapa D

\begin{tabular}{|l|l|}
\hline Nama Satelit & PALAPA D \\
\hline Posisi & $113^{0} \mathrm{E}$ \\
\hline EIRP & $54 \mathrm{dBW}$ \\
\hline Frekuensi Kerja & $\mathrm{Ku}-\mathrm{Band}$ \\
\hline Sensitifitas Satelit & $-140 \mathrm{dBW}$ \\
\hline TWTA (Travelling Wave Tube Amplifier) Power & $200 \mathrm{Watt}$ \\
\hline G/T & $8 \mathrm{~dB} /{ }^{\circ} \mathrm{K}$ \\
\hline
\end{tabular}

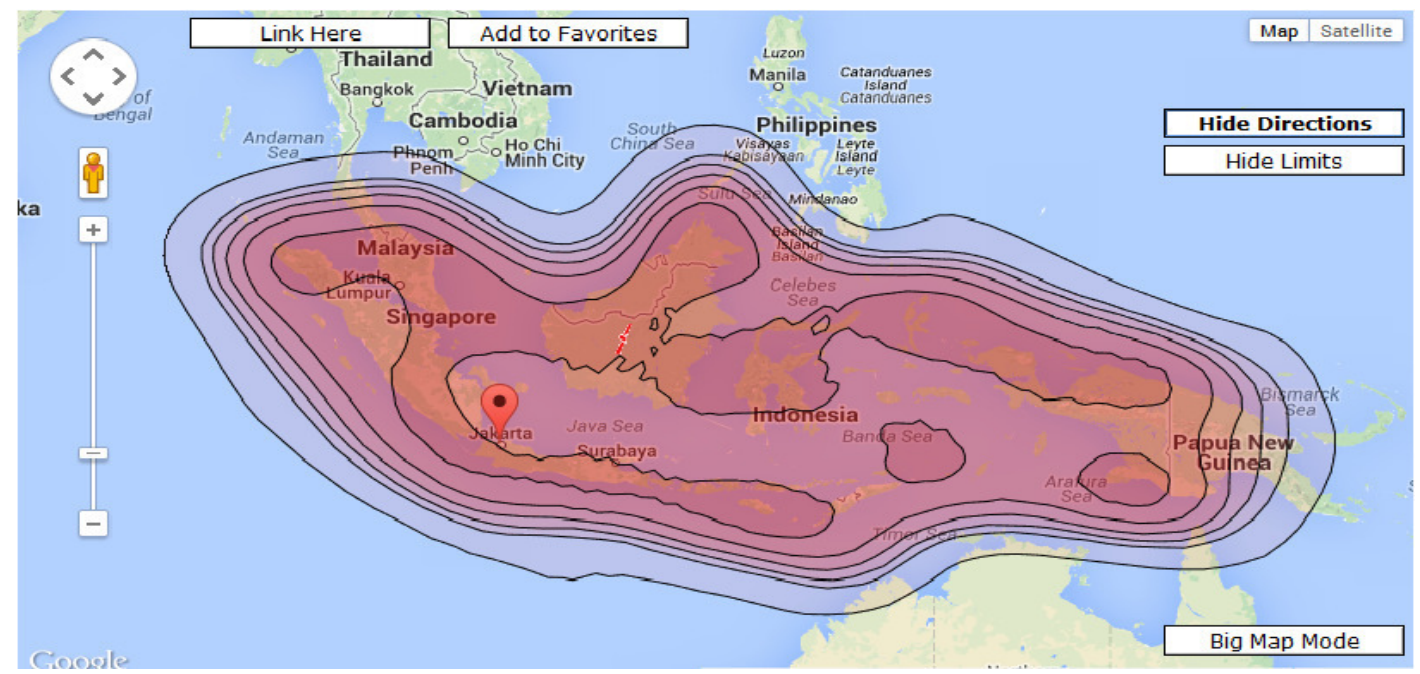

GAMBAR 3. Satelit parameter palapa D.

Dari gambar diatas menunjukan beam atau cakupan daerah yang dapat dijangkau oleh satelit. Terlihat pada gambar bahwa daerah pulau Sumatra, Kalimantan dan Jawa mendapat sinyal pancaran yg kuat dari satelit, namun pada daerah timur Indonesia daya pancar satelit kurang kuat. Ini mempengaruhi oleh letak satelit, dimana satelit Palapa D terletak di daerah barat 
Indonesia. Satelit Palapa D mengoperasikan hanya lima transponder Ku-Band pada frekuensi up-link 14.298 - $14.458 \mathrm{GHz}$ dan frekuensi down-link 12.250 - $12.710 \mathrm{GHz}$.

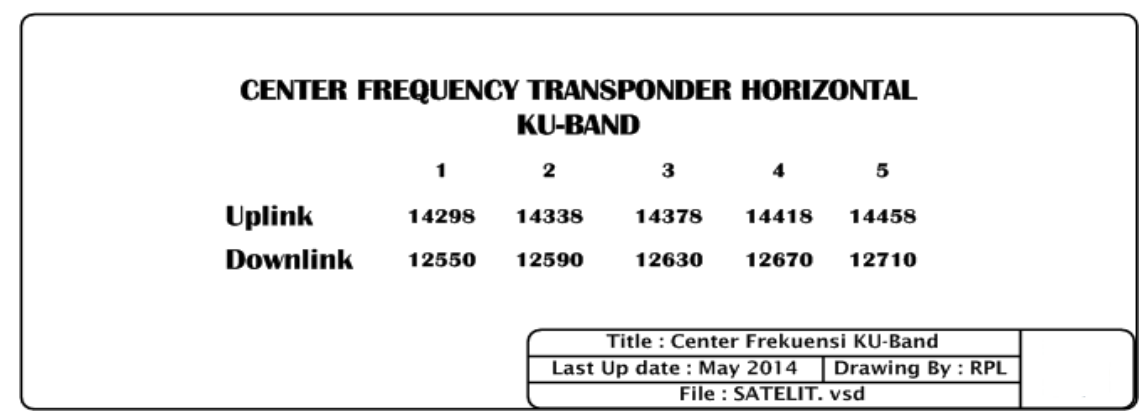

GAMBAR 4. Center Frekuensi Ku-Band satelit Palapa D

\section{Perancangan uplink}

\section{Penentuan Lokasi Stasiun Bumi Uplink}

Dalam perancangan sistem uplink maupun downlink harus diperhatikan kondisi lingkungan sekitar, jangan ada gedung, pohon, atau bangunan lain yang dapat menghalangi arah antena. Karena dalam komunikasi VSAT arah antena tidak boleh terhalang atau LOS (line of sight) untuk memaksimalkan daya yang dipancarkan atau diterima oleh antena.

\section{Perancangan Antena Uplink}

Untuk menentukan antena yang akan digunakan perlu dilakukan perhitungan untuk menentukan diameter antena dan HPA (High Power Amplifier) yang akan digunakan agar daya pancar antena dapat diterima oleh satelit. Uplink Path Loss atau redaman total arah uplink $\left(\mathrm{L}_{\text {Tot }}\right)_{\mathrm{up}}$ adalah merupakan besarnya total nilai pengurangan daya sinyal kirim dari stasiun bumi selama menempuh propagasi ke antena penerima pada satelit yang dipengaruhi oleh free space loss arah uplink, redaman hujan, redaman atmosfer dan pointing loss.

$$
\mathrm{L}_{\mathrm{Tot}}=\mathrm{FSL}_{\mathrm{uP}}+\text { Redaman Hujan }+ \text { Redaman Atmosfer }+ \text { Tracking Loss }
$$

\section{Perancangan Antena Downlink}

Downlink Path loss atau redaman total arah downlink $\left(\mathrm{L}_{\text {Tот }}\right)_{\text {down }}$ adalah merupakan besarnya total nilai pengurangan daya sinyal kirim dari satelit selama menempuh propagasi ke antena penerima pada stasiun bumi yang dipengaruhi oleh free spce loss arah downlink, redaman hujan, redaman atmosfir dan loss Tracking.

$$
\mathrm{L}_{\mathrm{Tot}}=\mathrm{FSL}_{\mathrm{DOwN}}+\text { Redaman Hujan }+ \text { Redaman Atmosfer }+ \text { Tracking Loss }
$$

\section{Perancangan Remote Vsat Mobile}

Remote VSAT terdiri atas beberapa komponen, yaitu antena, BUC (Block Up Converter), LNB (Low Noise Block), modem, dan kabel coaxial. Antena parabola VSAT Mobile dengan diameter reflektor $1.2 \mathrm{~m}$ mempunyai beberapa bagian yaitu reflektor dish, feed support, feedhorn, mounting, dan frame antena.

\section{Antena (ODU) Remote Vsat Mobile}

Antena parabola berfungsi sebagai penguat sinyal yang diterima dari satelit ataupun penguat sinyal yang dipancarkan ke arah satelit. Sinyal yang berasal dari BUC dipancarkan oleh feedhorn yang di tempatkan di titik fokus dari sebuah reflektor, untuk kemudian dipantulkan ke arah satelit oleh reflektor. Demikian pula gelombang radio yang diterima dari satelit dikumpulkan oleh feedhorn untuk kemudian disalurkan ke LNB. Tipe antena parabolic pada vsat yaitu: Offset, Center, Gregorian dan Cassegrain

\section{Perangkat (IDU) Remote Vsat Mobile Modem VSAT}

Modem digunakan untuk mengubah sinyal gelombang radio menjadi data. Pada sistem VSAT IP data yang dikeluarkan bukan lagi raw-data tetapi sudah dalam bentuk paket data IP. 
Demikian pula sebaliknya, packet data IP yang datang diubah oleh modem ke dalam bentuk gelombang radio. Modem HX-50 Hughes, merupakan modem dengan Voice over IP (VoIP) yang dirancang untuk menyediakan kemampuan VoIP terpadu, serta kecepatan akses tinggi untuk komunikasi data. HX-50 memiliki fleksibilitas untuk menangani berbagai kebutuhan jaringan IP enterprise.

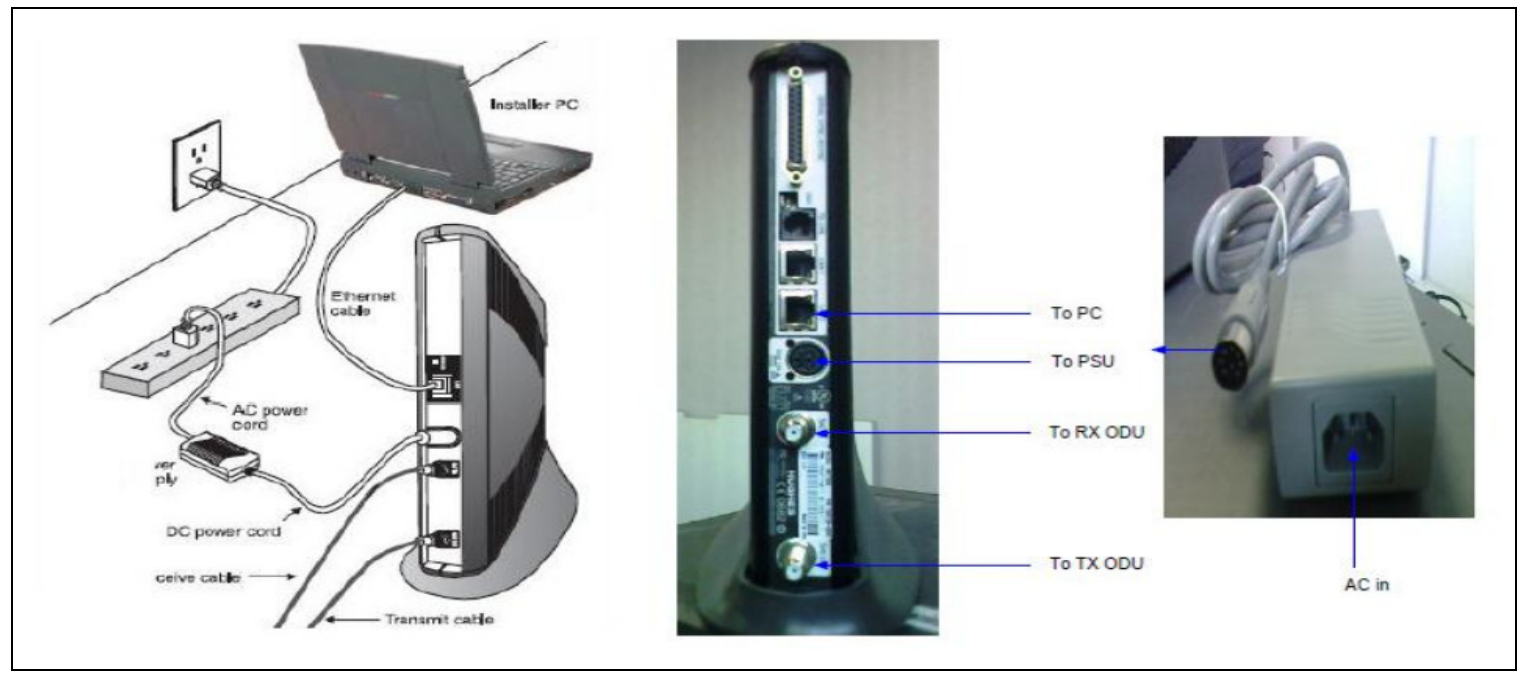

GAMBAR 5. Instalsi pada konfigurasi modem HX-50.

Modem digunakan untuk mengubah sinyal gelombang radio menjadi data. Pada sistem VSAT IP (Internet Protocol) data yang dikeluarkan bukan lagi raw data tetapi sudah dalam bentuk paket data IP. Demikian pula sebaliknya, packet data IP yang datang diubah oleh modem ke dalam bentuk gelombang radio. Modem Vsat yang termasuk jenis modem HX-50 Hughes, merupakan modem dengan Voice over IP (VoIP) yang dirancang untuk menyediakan kemampuan VoIP terpadu, serta kecepatan akses tinggi. Lampu indikator pada modem berfungsi memberikan tanda bahwa modem telah berjalan sampai level yang ada pada indikator tersebut, sehingga jika pada saat proses pointing lampu indikator pada modem tidak menyala semua itu menandakan bahwa modem mengalami gangguan sesuai dengan nyala lampu yang mati. Jika semua lampu pada modem menyala semua dan nilai SQF bagus maka langkah selanjutnya adalah mengecek fungsi antena VSAT tersebut dengan membuka situs atau web seperti facebook dsb, jika internet dapat digunakan dengan lancar maka proses pointing dikatakan sukses.

\section{ANALISA DAN PEMBAHASAN}

Pada sisi uplink ada beberapa hal yang akan mempengaruhi daya pancar stasiun bumi ke satelit, antara lain EIRP pada antena uplink dan cuaca. Untuk itu perlu adanya cara untuk menambah ketahanan terhadap cuaca dengan cara menaikkan nilai EIRP stasiun bumi uplink.

\section{Perhitungan EIRP antena Uplink}

Untuk perhitungan EIRP antena pemancar dilakukan dengan menggunakan rumus berikut:

$$
[E I R P]_{\mathrm{dB}}=\mathrm{P}_{\mathrm{TX}}(\mathrm{dBW})-\mathrm{L}_{\mathrm{FTX}}(\mathrm{dB})+\mathrm{G}_{\mathrm{dB}}
$$

Dimana:

$\mathrm{P}_{\mathrm{TX}} \quad: 5 \mathrm{Watt}=6.9 \mathrm{dBW}$

LFTX : 0,52 dB Feeder Anrew Heliax LDF4-50A (losses: 0,26/m) sepanjang $5 \mathrm{~m}$

$\mathrm{RSL}_{\text {(sat): }}$ : mendekati batas sensitifitas satelit $=-140 \mathrm{dBW}$

$\mathrm{G}_{(\text {sat })} \quad: 98 \mathrm{dBi}$

Maka Gain antena:

$$
\mathrm{RSL}_{\text {(sat) }} \quad=\mathrm{EIRP}_{\mathrm{UP}}-\mathrm{L}_{\mathrm{TOT}}
$$




$$
\begin{aligned}
& -140 \mathrm{dBW}=\mathrm{EIRP}_{\mathrm{UP}}-215,89 \mathrm{~dB} \\
& \text { EIRP }_{\mathrm{UP}}=215,89-140 \mathrm{dBW} \\
& \mathrm{P}_{\mathrm{TX}}(\mathrm{dBW})-\mathrm{L}_{\mathrm{FTX}}(\mathrm{dB})+\mathrm{G}_{\mathrm{dB}} \quad=75,89 \mathrm{dBW} \\
& 6,9 \mathrm{dBW}-0,52+\quad \mathrm{G}_{\mathrm{dB}} \quad=75,89 \mathrm{dBW} \\
& \mathrm{G}_{\mathrm{dB}}=69,51 \mathrm{dBi}
\end{aligned}
$$

Dengan mengetahui $\mathrm{G}$ antena uplink yang akan digunakan, maka akan dapat ditentukan diameter antena dengan menggunakan rumus. $(\eta=$ efisiensi aperture $0,55-0,814)$

$$
\begin{aligned}
& \mathrm{G}_{\max }(\mathrm{dBi})=10 \log \eta(\pi . \mathrm{D} \cdot f / \mathrm{C})^{2} \\
& 9,51 \mathrm{dBi}=10 \log (0,55)\left(3,14 \times \mathrm{D} \times 14458 / 3 \times 10^{8}\right)^{2} \\
& 69,51 \mathrm{dBi}=10 \log (0,55)\left(2,28 \times 10^{-8}\right) \\
& \mathrm{D} \quad=69,51 / 80,96 \\
& \quad=0,85 \mathrm{~m}
\end{aligned}
$$

Untuk mendapatkan daya pancar antena uplink atau EIRP sebesar 75,83 dBW diperlukan antena dengan diameter sebesar $0,85 \mathrm{~m}$

$$
[E I R P]_{\mathrm{dB}}=\mathrm{P}_{\mathrm{TX}}(\mathrm{dBW})-\mathrm{L}_{\mathrm{FTX}}(\mathrm{dB})+\mathrm{G}_{\mathrm{dB}}
$$

Dimana:

$\mathrm{P}_{\mathrm{TX}}=5 \mathrm{Watt}=6.9 \mathrm{dBW}$

$\mathrm{L}_{\mathrm{FTX}}=0,52 \mathrm{~dB}$ Feeder Anrew Heliax LDF4-50A (losses:0,26/m) sepanjang $5 \mathrm{~m}$

$\mathrm{G}_{\mathrm{dB}}=69,51 \mathrm{dBi}$

Maka nilai EIRP:

$$
\begin{aligned}
{[E I R P]_{\mathrm{dB}} } & =\mathrm{P}_{\mathrm{TX}}(\mathrm{dBW})-\mathrm{L}_{\mathrm{FTX}}(\mathrm{dB})+\mathrm{G}_{\mathrm{dB}} \\
& =6,9 \mathrm{dBW}-0,52 \mathrm{~dB}+69,51 \mathrm{dBi} \\
& =75,89 \mathrm{dBW}
\end{aligned}
$$

Jika salah satu jenis antena yang ada dirancang, misal prodeline 1,2 $\mathrm{m}$ dimasukkan kedalam perssamaan-persamaan diatas akan menghasilkan $\mathrm{G}_{\max }(\mathrm{dBi})$ sebagai berikut:

$$
\begin{aligned}
\mathrm{G}_{\max }(\mathrm{dBi}) & =10 \log \eta(\pi \cdot \mathrm{D} . f / \mathrm{C})^{2} \\
& =10 \log \left(0,55\left(3,14 \times 1,2 \times 14458 / 3 \times 10^{8}\right)^{2}\right. \\
& =10 \log \left(1,81 \times 10^{-8}\right) \\
& =77,4 \mathrm{dBi} \\
{[E I R P]_{\mathrm{dB}} } & =\mathrm{P}_{\mathrm{TX}}(\mathrm{dBW})-\mathrm{L}_{\mathrm{FTX}}(\mathrm{dB})+\mathrm{G}_{\mathrm{dB}} \\
& =6,9 \mathrm{dBW}-0,52 \mathrm{~dB}+77,4 \mathrm{dBi} \\
& =83,78 \mathrm{dBW}
\end{aligned}
$$

\section{Perhitungan Uplink Path Loss}

FSL untuk antena pemancar dapat ditentukan dengan cara, diketahui frekuensi penerimaan uplink yang digunakan adalah $14,458 \mathrm{GHz}$ dan jarak dari satelit ke antena penerima $36000 \mathrm{Km}$.

$$
\begin{aligned}
\mathrm{FSL}_{\mathrm{UP}} & (\mathrm{dB})=20 \log (d)+20 \log (f)+92,44 \\
& =20 \log (36000)+20 \log (14,458)+92,44 \\
& =91,12+23,20+92,44 \\
& =206,76 \mathrm{~dB}
\end{aligned}
$$

Data dari pengamatan grafik dan tabel diketahui nilai redaman hujan sebesar $8 \mathrm{~dB}$, redaman atmosfer $0,73 \mathrm{~dB}$ dan Loss Tracking sebesar 0,4 dB. Maka uplink path loss dapat diketahui sebagai berikut:

$$
\begin{aligned}
\mathrm{L}_{\mathrm{Tot}} & =\mathrm{FSL}_{\mathrm{UP}}+\text { Redaman Hujan }+ \text { Redaman Atmosfer }+ \text { Tracking Loss } \\
& =206,76 \mathrm{~dB}+8 \mathrm{~dB}+0,73 \mathrm{~dB}+0,4 \mathrm{~dB} \\
& =215,89 \mathrm{~dB}
\end{aligned}
$$

\section{C/N Uplink}

Persamaan uplink untuk transmisi dapat ditulis secara langsung dengan mensubtitusikan nilainilai kedalam persamaan dasar link dibawah ini:

$$
\mathrm{C} / \mathrm{N}_{\mathrm{UP}}=\mathrm{EIRP}_{\mathrm{UP}}-\mathrm{L}_{\mathrm{TOT}}+\mathrm{G} / \mathrm{T}_{\mathrm{SAT}}-\mathrm{k}-10 \log \mathrm{B}
$$


Dimana:

$$
\begin{aligned}
& \text { EIRP }_{\mathrm{UP}} \quad \text { : } 75,89 \mathrm{dBW} \\
& \text { L } \quad: 215,89 \mathrm{~dB} \\
& \mathrm{G} / \mathrm{T}_{\mathrm{SAT}} \quad \text { : G/T Satelit } 8 \mathrm{~dB} /{ }^{0} \mathrm{~K} \\
& \mathrm{~K} \text { : Konstanta Boltzman }=-228.6\left(\mathrm{dBW} /{ }^{0} \mathrm{~K}-\mathrm{Hz}\right) \\
& \text { B : Bandwidth Ocuupation }=36 \mathrm{MHz} \\
& \mathrm{C} / \mathrm{N}_{\mathrm{UP}}=\mathrm{EIRP}_{\mathrm{UP}}-\mathrm{L}_{\mathrm{TOT}}+\mathrm{G} / \mathrm{T}_{\mathrm{SAT}}-\mathrm{k}-10 \log \mathrm{B} \\
& =75,89-215,89+8+228,6-10 \log 36 \times 10^{6} \\
& =21,03 \mathrm{~dB}
\end{aligned}
$$

Dengan demikian menggunakan uplink berdiameter 1,2 dalam perancangan ini didapatkan EIRP sebesar 83,78 dBW. Ini akan mengakibatkan perubahan nilai pada $\mathrm{C} / \mathrm{N}$ pada sisi uplink.

$$
\mathrm{C} / \mathrm{N}_{\mathrm{UP}}=\mathrm{EIRP}_{\mathrm{UP}}-\mathrm{L}_{\mathrm{TOT}}+\mathrm{G} / \mathrm{T}_{\mathrm{SAT}}-\mathrm{k}-10 \log \mathrm{B}
$$

Dimana:

$$
\begin{aligned}
& \text { EIRP }_{\mathrm{UP}} \quad: 83,78 \mathrm{dBW} \\
& \mathrm{L}_{\mathrm{TOT}} \quad: 215,89 \mathrm{~dB} \\
& \begin{array}{ll}
\mathrm{G} / \mathrm{T}_{\mathrm{SAT}} & : \mathrm{G} / \mathrm{T} \text { Satelit } 8 \mathrm{~dB} /{ }^{0} \mathrm{~K} \\
\mathrm{~K} \quad: & \text { Konstanta Boltzman }=-228.6\left(\mathrm{dBW} /{ }^{0} \mathrm{~K}-\mathrm{Hz}\right) \\
\mathrm{B} \quad: \text { Bandwidth Ocuupation }=36 \mathrm{MHz}
\end{array} \\
& \begin{aligned}
\mathrm{C} / \mathrm{N}_{\mathrm{UP}} & =83,78-215,89+8+228,6-10 \log 36 \times 10^{6} \\
& =28,92 \mathrm{~dB}=29 \mathrm{~dB}
\end{aligned}
\end{aligned}
$$

\section{Redaman Hujan Uplink}

Efek hujan adalah atenuasi atau redaman yang ditimbulkan oleh karena adanya hujan turun. Nilai redaman hujan bersifat fluktuatif atau berubah-ubah tergantung nilai curah hujan dan lintasan curah hujan pada suatu daerah.

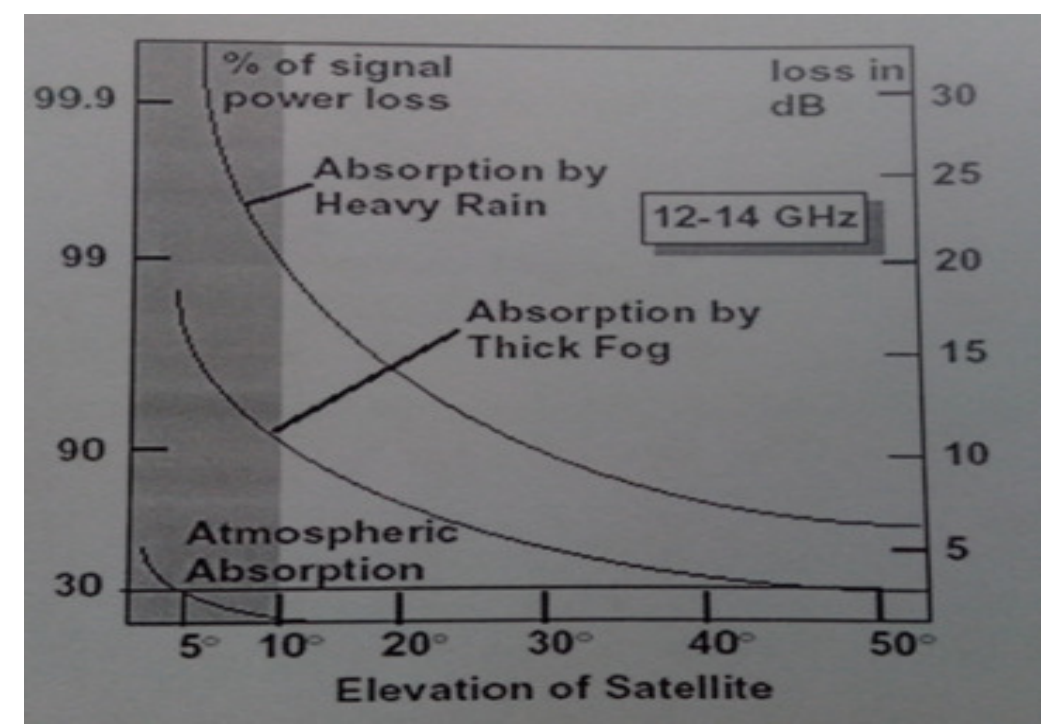

GAMBAR 6. Grafik penentuan nilai redaman hujan

Dari grafik di atas terlihat bahwa nilai redaman hujan pada frekuensi ku-band untuk range 12 $\mathrm{GHz}-14 \mathrm{GHz}$ pada sudut elevasi $70,9^{\circ}$ sekitar $8 \mathrm{~dB}$.

\section{Redaman Atmosfer Uplink}

Rugi-rugi ini adalah rugi-rugi yang disebabkan oleh kumpulan gas berada pada atmosfer bumi, gas ini dapat berupa oksigen dan uap air yang menyebabkan redaman kepada sinyal. Karakteristik dari rugi-rugi ini tergantung kepada frekuensi, sudut elevasi dan ketinggian diatas 
permukaan laut. Untuk frekuensi dibawah $10 \mathrm{GHz}$, besar rugi atmosfer ini dapat diabaikan, tetapi jika menggunakan frekuensi diatas $10 \mathrm{GHz}$, dengan sudut elevasi yang kecil, maka rugi ini diperlukan diperhitungkan sesuai tabel berikut. Dari tabel 2.3 terlihat nilai redaman atmosfer untuk frekuensi kerja $13<$ f memiliki nilai redaman sebesar $0.73 \mathrm{~dB}$. Ini dikarenakan frekuensi kerja antena uplink berada pada frekuensi $14.458 \mathrm{GHz}$.

\section{Loss Tracking Uplink}

Ketika sebuah link satelit dibangun, kondisi yang diharapkan secara teori adalah bahwa posisi dari stasiun bumi diatur sedemikian rupa sehingga mendapatkan gain yang maksimum. Tetapi pada prakteknya, akan terdapat selisih sudut dalam beberapa derajat yang terjadi dalam penjejakan satelit yang akan menimbulkan penurunan gain beberapa $\mathrm{dB}$.

Untuk beberapa keadaan menggunakan frekuensi Ku-Band, dapat dilihat pada tabel sbb;

TABEL 1. Karakteristik Stasiun Bumi Ku-band dengan Efisiensi 60\%

\begin{tabular}{|c|c|c|c|c|l|}
\hline $\begin{array}{c}\text { Diameter } \\
\text { Antena }\end{array}$ & TX Gain & RX Gain & $\begin{array}{c}\text { Uplink } \\
\text { Losses }\end{array}$ & $\begin{array}{c}\text { Downlink } \\
\text { Losses }\end{array}$ & \multicolumn{1}{|c|}{ Tracking } \\
\hline 1,2 & 42,6 & 40,5 & 0,4 & 0,2 & FIXED \\
1,8 & 46,1 & 44 & 0,7 & 0,5 & FIXED \\
2,4 & 48,7 & 46,6 & 1,1 & 0,8 & FIXED \\
3,7 & 52,5 & 50,3 & 1,2 & 0,9 & MANUAL \\
5,6 & 56,1 & 53,9 & 0,8 & 0,7 & MANUAL \\
7 & 58 & 55,8 & 0,5 & 0,5 & STEPTRACK \\
8 & 59,2 & 57 & 0,5 & 0,5 & STEPTRACK \\
\hline
\end{tabular}

Terlihat pada tabel diatas bahwa nilai Loss Tracking berbeda-beda tergantung ukuran diameter antena dan cara tracking yang dilakukan. Untuk perancangan ini menggunakan antena 1.2meter diasumsikan memiliki nilai redaman skitar $0.4 \mathrm{~dB}$.

\section{Pembahasan Downlink}

Pada sisi downlink ada beberapa hal yang akan mempengaruhi daya pancar satelit ke stasiun bumi penerima, antara lain cuaca dan antena penerima itu sendiri. Untuk itu perlu adanya cara untuk menambah ketahanan terhadap cuaca dengan cara menaikkan nilai gain pada antena penerima dengan menaikkan besar diameter antena penerima.

\section{Perhitungan Downlink Path Loss}

FSL untuk antena penerima dapat ditentukan dengan cara diketahui frekuensi penerimaan downlink yang digunakan adalah $12,710 \mathrm{GHz}$ dan jarak dari satelit ke antena penerima 36000 $\mathrm{Km} .4$

$$
\begin{aligned}
\mathrm{FSL}_{\text {DOWN }}(\mathrm{dB}) & =20 \log (d)+20 \log (f)+92,44 \\
& =20 \log (36000)+20 \log (12,710)+92,44 \\
& =91,12+22,08+92,44 \\
& =205,64 \mathrm{~dB}
\end{aligned}
$$

Dari data pengamatan grafik dan tabel diketahui nilai redaman hujan sebesar $8 \mathrm{~dB}$, redaman atmosfer $0,53 \mathrm{~dB}$ dan Loss Tracking sebesar 0,2 dB, maka downlink path loss dapat diketahui sebagai berikut:

$$
\begin{aligned}
\mathrm{L}_{\text {Tot }} & =\text { FSL }_{\text {DOwN }}+\text { Redaman Hujan }+ \text { Redaman Atmosfer + Tracking Loss } \\
& =205,64 \mathrm{~dB}+8 \mathrm{~dB}+0,53 \mathrm{~dB}+0,2 \mathrm{~dB} \\
& =214.37 \mathrm{~dB}
\end{aligned}
$$

RSL (Receive Signal Level)

RSL merupakan besar daya yang diterima oleh antena penerima stasiun bumi dari satelit dimana besar nilai RSL akan mempengaruhi nilai fading margin stasiun bumi penerima. Untuk melakukan perhitungan terhadap RSL stasiun bumi perlu diketahui beberapa parameter berikut:

$$
\begin{array}{ll}
\text { EIRPsat } & =54 \mathrm{dBW} \\
\mathrm{L}_{\mathrm{Tot}} & =214.37 \mathrm{~dB} \\
\mathrm{RSL} & =-70 \mathrm{dBW} \text { (diasumsikan) } \\
\text { Gain LNB } & =60 \mathrm{~dB} \\
\mathrm{RSL}=\text { EIRPsat }- \text { Ltot }+\mathrm{G}_{\mathrm{RX}}+\mathrm{G}_{\mathrm{LNB}}
\end{array}
$$




$$
\begin{aligned}
& -70=54-214,37+\mathrm{G}_{\mathrm{RX}}+60 \\
& \mathrm{G}_{\mathrm{RX}}=30,37 \mathrm{dBi}
\end{aligned}
$$

Jika dengan mengetahui $\mathrm{G}$ antena uplink dipasaran skyware, maka akan ditentukan diameter antena dengan menggunakan rumus:

$$
\begin{aligned}
\mathrm{G}_{\max } & =10 \log \eta(\pi . \mathrm{D} . f / \mathrm{C})^{2} \\
30.37 & =10 \log (0,55)\left(3,14 \times \mathrm{D} \times 12710 \times 10^{6} / 3 \times 10^{8}\right)^{2} \\
\mathrm{D} & =-2.59(1.769) / 30.37=0.14 \mathrm{~m} \\
\mathrm{D} & =14 \mathrm{~cm} \\
\mathrm{RSL} & =\text { EIRPsat }-\mathrm{Ltot}+\mathrm{G}_{\mathrm{RX}}+\mathrm{G}_{\mathrm{LNB}} \\
& =54-214.37+30.37+60 \\
& =-70 \mathrm{dBm}
\end{aligned}
$$

Dengan demikian antena $1,2 \mathrm{~m}$ memiliki nilai

$$
\begin{aligned}
\mathrm{G}_{\max } & =10 \log \eta(\pi . \mathrm{D} . f / \mathrm{C})^{2} \\
& =10 \log (0,55)\left(3,14 \times 1,2 \times 12710 \times 10^{6} / 3 \times 10^{8}\right)^{2} \\
& =-2.59(2.54)=-6.57 \mathrm{dBi} \\
\mathrm{RSL} & =\text { EIRPsat }- \text { Ltot }+\mathrm{G}_{\mathrm{RX}}+\mathrm{G}_{\mathrm{LNB}} \\
& =54-214.37+(-6.57)+60 \\
& =-86.06 \mathrm{dBm}
\end{aligned}
$$

\section{Perhitungan Fading Margin}

Fading margin adalah level daya yang harus dicadangkan yang besarnya merupakan selisih antara daya rata-rata yang sampai dipenerima dan level sensitivitas penerima. Berdasarkan perhitungan standar fading margin untuk komunikasi vsat ukuran diameter antena yang kecil pada frekuensi tinggi sangat rentan terhadap redaman. Untuk mengurangi redaman diperlukan penggunaan antena penerima lebih besar, seperti antena penerima berdiameter $1,2 \mathrm{~m}$ akan mengahasilkan nilai fading margin yang lebih besar.

$$
\mathrm{F} \quad=\mathrm{RSL}-\mathrm{R}_{\mathrm{th}}
$$

Dimana:

$$
\begin{array}{ll}
\mathrm{RSL} & =-86.06 \mathrm{dBm} \\
\mathrm{R}_{t h} & =\text { level sensitivitas penerima (treshold) }(\mathrm{dBm} \text { atau } \mathrm{dBW}) \\
& \text { Diketahui level sensitivitas penerima pada antena }-80 \mathrm{dBm} \\
\mathrm{F} & =\mathrm{RSL}-\mathrm{R}_{t h} \\
& =-86.06-(-80)=-6.06 \mathrm{dBm}
\end{array}
$$

Dengan menggunakan antena 1,2 m akan menghasilkan nilai fading margin sebesar $-6.06 \mathrm{dBm}$

\section{Perhitungan Derau Suhu Sistem}

Adalah penjumlahan dari derau suhu penerima, derau suhu antena termasuk feeder dan derau suhu dari langit. Besarnya derau suhu ini dapat dihitung dengan menggunakan persamaan berikut:

$$
\mathrm{T}_{\text {sistem }}=\mathrm{T}_{\text {ant }} / \mathrm{L}+(1-1 / \mathrm{L}) \mathrm{T}_{0}+\mathrm{T}_{\mathrm{e}}
$$

Dimana:

$$
\begin{aligned}
& \mathrm{L}=1 \mathrm{~dB} \\
& \mathrm{~T}_{\mathrm{e}}=45^{0} \mathrm{~K} \text { (Spesifikasi LNB) } \\
& \mathrm{T}_{0}=\text { suhu standar } 290^{\circ} \mathrm{K} \\
& \mathrm{T}_{\text {ant }} \quad=30^{\circ} \mathrm{K} \text { (Spesifikasi antena penerima) } \\
& \mathrm{T}_{\text {system }}=\mathrm{T}_{\text {ant }} / \mathrm{L}+(1-1 / \mathrm{L}) \mathrm{T}_{0}+\mathrm{T}_{\mathrm{e}} \\
& =30 / 1+(1-1 / 1) 290+45 \\
& =75^{\circ} \mathrm{K}
\end{aligned}
$$

\section{Perhitungan Kepekaan Sistem (Figure of Merit)}

Ini dapat disebut juga Gain-to-Noise Temperature Ratio. Parameter ini sering digunakan pada setiap komunikasi dengan menggunakan ruang bebas yang didefinisikan sebagai $\mathrm{G} / \mathrm{T}_{\mathrm{SB}}=\mathrm{G}_{\mathrm{dB}}-$ $10 \log \mathrm{T}_{\text {sys }}$ 
Dimana:

$$
\begin{aligned}
\mathrm{G}_{\mathrm{dB}} & =-6.57 \mathrm{dBi} \\
\mathrm{T}_{\mathrm{SB}} & =75^{0} \mathrm{~K} \\
\mathrm{G} / \mathrm{T}_{\mathrm{SB}} & =\mathrm{G}_{\mathrm{dB}}-10 \log \mathrm{T}_{\mathrm{sys}} \\
& =-6.57-10 \log 75 \\
& =25.3 \mathrm{~dB} /{ }^{0} \mathrm{~K}
\end{aligned}
$$

\section{Perhitungan C/N Downlink}

Persamaan downlink untuk transmisi dari satelit menuju stasiun bumi penerima dapat ditulis secara langsung dengan mensubtitusikan nilai-nilai kedalam persamaan dasar link dibawah ini.

$$
\mathrm{C} / \mathrm{N}_{\text {DOWN }}=\mathrm{EIRP}_{\text {DOWN }}-\mathrm{L}_{\mathrm{TOT}}+\mathrm{G} / \mathrm{T}_{\mathrm{SB}}-\mathrm{k}-10 \log \mathrm{B}
$$

Dimana:

$$
\begin{aligned}
& \text { EIRPsat }=54 \mathrm{dBW} \\
& \text { FSL }_{\text {DOwN }}(\mathrm{dB})=205,64 \mathrm{~dB} \\
& \mathrm{~L}_{\mathrm{ABS}}=\text { Rugi-rugi Absorbsi } 0,73 \mathrm{~dB} \\
& \mathrm{G} / \mathrm{T}_{\mathrm{SB}}=25.3 \mathrm{~dB} /{ }^{\circ} \mathrm{K} \\
& \mathrm{K}=\text { Konstanta Boltzman }=-228.6\left(\mathrm{dBW} /{ }^{\circ} \mathrm{K}-\mathrm{Hz}\right) \\
& \mathrm{B}=\text { Bandwidth Ocuupation }=36 \mathrm{MHz} \\
& \mathrm{C} / \mathrm{N}_{\text {DOWN }}=\mathrm{EIRP}_{\text {DOWN }}-\mathrm{L}_{\text {TOT }}+\mathrm{G} / \mathrm{T}_{\mathrm{SB}}-\mathrm{K}-10 \log \mathrm{B} \\
& =54-214.37 \mathrm{~dB}+25.3+228.6-10 \log 36 \times 10^{6} \\
& =17.97 \mathrm{~dB}=18 \mathrm{~dB}
\end{aligned}
$$

\section{Perhitungan C/N Total}

Nilai dari $\mathrm{C} / \mathrm{N}$ total merupakan penjumlahan dari $\mathrm{C} / \mathrm{N}$ up-link dan $\mathrm{C} / \mathrm{N}$ down-link dengan menggunakan rumus sebagai berikut:

$$
(C / N)=\frac{1}{\frac{1}{(C / N) U_{p l i n k}}+\frac{1}{(C / N) \text { Downlink }}}
$$

Dimana:

$$
\begin{aligned}
& \mathrm{C} / \mathrm{N} \text { Uplink } \quad=29 \mathrm{~dB} \\
& \mathrm{C} / \mathrm{N} \text { Downlink }=18 \mathrm{~dB} \\
& \left(\mathrm{C} / \text { N)total }=\frac{1}{\frac{1}{29}+\frac{1}{18}}\right. \\
& \text { Maka C } / \mathrm{N}_{\text {total }}=11.11 \mathrm{~dB}
\end{aligned}
$$

Dari keseluruhan perhitungan yang telah dilakukan pada penelitian ini akan menghasilkan perancangan seperti tabel dibawah ini:

TABEL 2. Perhitungan $\mathrm{C} / \mathrm{N}$ Margin

\begin{tabular}{|l|c|c|c|c|}
\hline $\begin{array}{c}\text { Perhitungan } \\
\text { Antena }\end{array}$ & EIRP $(\mathrm{dBW})$ & $\begin{array}{c}\text { Redaman Total } \\
(\mathrm{dB})\end{array}$ & $\mathrm{G} / \mathrm{T}\left(\mathrm{dB} /{ }^{\circ} \mathrm{K}\right)$ & $\mathrm{C} / \mathrm{N}(\mathrm{dB})$ \\
\hline Uplink $1,2 \mathrm{~m}$ & 69,51 & 215,89 & 8 & 29 \\
\hline Downlink $1,2 \mathrm{~m}$ & 54 & 205.64 & 25.3 & 18 \\
\hline
\end{tabular}

Dari tabel 2, didapat beberapa poin untuk menghasilkan kualitas link vsat yang dapat menambah ketahanan terhadap redaman hujan.

- Antena uplink sesuai perhitungan adalah antena berdiameter $0,85 \mathrm{~m}$, namun untuk menghasilkan daya pancar yang optimal dan meningkatkan ketahanan terhadap redaman hujan maka digunakan antena berdiameter $1,2 \mathrm{~m}$.

- HPA yang digunakan pada perhitungan adalah HPA 5 Watt, namun untuk memaksimalkan daya pancar antena maka besar HPA yang digunakan dapat bervariasi nilainya sesuai kebutuhan uplink.

- Antena downlink sesuai perhitungan adalah antena berdiameter $14 \mathrm{~cm}$, namun untuk menghasilkan daya terima yang optimal dan meningkatkan ketahanan terhadap redaman hujan maka digunakan antena berdiameter $1200 \mathrm{~cm}$ atau $1,2 \mathrm{~m}$. 


\section{KESIMPULAN}

Dari perhitungan sistem uplink dengan antena pemancar berdiameter 1,2 $\mathrm{m}$ dan sistem downlink dengan penerima $1,2 \mathrm{~m}$ didapat nilai $\mathrm{C} / \mathrm{N}_{\text {uplink }} 29 \mathrm{~dB}$ dan nilai $\mathrm{C} / \mathrm{N}_{\text {downlink }}$ sebesar $18 \mathrm{~dB}$ sehingga $\mathrm{C} / \mathrm{N}$ total $11,11 \mathrm{~dB}$. Pada penghitungan didapat RSL untuk perancangan antena VSAT mobile ini dengan antena penerima $1,2 \mathrm{~m}$ adalah $-86,06 \mathrm{dBm}$, membuktikan bahwa perhitungan yang dilakukan untuk perancangan antena VSAT mobile pada frekuensi ku-band dapat digunakan sebagai acuan untuk realisasi sebagai akses komunikasi data kedepannya yang dapat dibawa ke manapun.

\section{DAFTAR PUSTAKA}

[1] Ha. Tri T., "Digital Sateliite Communication", McGraw Hill., Canada, 1990.

[2] Pamungkas, Wahyu, "Diktat Kuliah Komunikasi Satelit",

[3] Lutfy, "Teori Tentang Satelit dan Vsat", CV. Penerbit Alumni, Jakarta, 2014.

[4] Roddy.Dennis, "Satellite Communication 2nd Edition”, Mc Graw-Hill. Canada, 1996.

[5] Indosat. PT, "POINT TO PALAPA", http://www.palapasat.com/palapad.php

[6] PALAPA-D Characteristic.html, 03.05.2014.

[7] Palapa Satellite Indosat Singapore, "World's leading provider of telecommunications services",http://www.indosatsingapore.com/infrastructure/palapa-satellite.html, 17.05.2014.

[8] Fatonah. Nurul, "Design Link Budget", http://www.academia.edu/4831868/Design Link Budget/ NURUL FATONAH TELKOM PURWOKERTO 2013.pdf, 09.05.2014. 